\title{
RADIOCARBON DATING OF A VERY LARGE GRANDIDIER BAOBAB, THE GIANT OF BEVOAY
}

\author{
ADRIAN PATRUT ${ }^{\mathrm{a}, \mathrm{b} *}$, ROXANA T. PATRUT', \\ JEAN-MICHEL LEONG POCK-TSY ${ }^{d}$, STEPHAN WOODBORNE ${ }^{\mathrm{e}}$, \\ LASZLO RAKOSYc, ILEANA-ANDREEA RATIU ${ }^{\mathrm{b}}$, \\ JENŐ BODIS ${ }^{b}$, PASCAL DANTHUf
}

\begin{abstract}
The article presents the AMS (accelerator mass spectrometry) radiocarbon dating results of the Giant of Bevoay, which is a very large Grandidier baobab (Adansonia grandidieri Baill.) of Madagascar. The investigation of this baobab shows that it has a cluster structure, which consists of 3 perfectly fused stems. The calculated wood volume of the tree is $520 \mathrm{~m}^{3}$, which makes it the third largest Grandidier baobab and also the third largest individual of all Adansonia species. Two samples were collected from the outer part of the stems. The oldest dated sample segment had a radiocarbon date of $525 \pm 23 \mathrm{BP}$, which corresponds to a calibrated age of $585 \pm 10$ years. According to this value, the Giant of Bevoay is $825 \pm 50$ years old.
\end{abstract}

Keywords: AMS radiocarbon dating, Adansonia grandidieri, tropical trees, age determination.

\section{INTRODUCTION}

The Adansonia genus, that belongs to the Bombacoideae, a subfamily of Malvaceae, contains eight or nine species. One or two species originate from the tropical savanna of Africa, six species are endemic to Madagascar and one species grows only in Australia [1-6].

a Babeş-Bolyai University, Faculty of Chemistry and Chemical Engineering, 11 Arany Janos, RO-400028, Cluj-Napoca, Romania.

b Babeş-Bolyai University, Raluca Ripan Institute for Research in Chemistry, 30 Fantanele, RO-400294 Cluj-Napoca, Romania.

c Babeş-Bolyai University, Faculty of Biology and Geology, 44 Republicii, RO-400015, ClujNapoca, Romania.

d Drfgrn-fofifa, Antananarivo, Madagascar.

e iThemba LABS, Private Bag 11, WITS 2050, South Africa.

f Cirad, UPR HortSys, Montpellier, France.

* Corresponding author: apatrut@gmail.com 
ADRIAN PATRUT, ROXANA T. PATRUT, JEAN-MICHEL LEONG POCK-TSY, STEPHAN WOODBORNE, LASZLO RAKOSY, ILEANA-ANDREEA RATIU, JENŐ BODIS, PASCAL DANTHU

In 2005, we initiated an extensive research project for elucidating several controversial or poorly understood aspects related to the architecture, development and age of the African baobab (Adansonia digitata L.). The research is based on our original methodology, which is not limited to dead specimens, but also allows to investigate and date live individuals. This approach uses AMS radiocarbon dating of tiny wood samples collected from inner cavities, deep incisions in the trunk, broken stems and from the outer part of trunk/stems of large baobabs [7-17]. We found that most large and old African baobabs are multi-stemmed and exhibit preferentially ring-shaped structures. The oldest African baobabs were found to have ages up to 2,500 years [10, 11,13-15].

In 2013, our research on the Adansonia genus was extended to big individuals of the most widespread three Malagasy species, namely the Fony baobab (Adansonia rubrostipa Jum. \& H. Perrier), the Za baobab (Adansonia za Baill.) and the Grandidier baobab (Adansonia grandidieri Baill.), which grow in the west and south of the Big Island [6,19-22].

The Grandidier baobab, which is called Reniala (or Renala) by natives (in Masikoro, i.e., "Mother of the Forest"), is the largest and most famous of the six Adansonia species of Madagascar. A. grandidieri is represented by big trees with columnar trunks and flat-topped crowns with almost horizontal large branches $[2,3,6]$.

Until 1998, A. grandidieri was observed in a limited number of locations in southwestern Madagascar. Consequently, according to the IUCN Red List, A. grandidieri was classified as endangered [23]. New investigations, based on photo-interpretation of very high resolution satellite images and validated by field investigations, demonstrated that $A$. grandidieri is distributed in a larger area than previously believed and its population is much larger than older estimates. According to recent research, the total population of $A$. grandidieri, which covers an area of $26,232 \mathrm{~km}^{2}$ along the Mangoky river and in the west part of the Menabe region, is around 1.2-1.3 million mature specimens. However, the species is still classified as endangered for a new reason, namely the predicted population decline of at least $50 \%$ over the next three generations $[18,21,23]$.

The biggest $A$. grandidieri can be found in the Morombe area, especially in the so-called Andombiry Forest. The Andombiry Forest hosts or hosted three very large $A$. grandidieri specimens, with wood volumes of over $500 \mathrm{~m}^{3}$, namely the Big Reniala of Isosa, the famous Tsitakakoike, which died in 2019, and Tsitakakantsa [20,21].

Here we present the investigation and AMS radiocarbon dating results of another giant specimen, the Giant of Bevoay, which is situated on the lower course of the Mangoky river. 


\section{RESULTS AND DISCUSSION}

The Giant of Bevoay and its area. The baobab is located on a small hill, in the proximity of a stone quarry, at $1 \mathrm{~km}$ from the southern (left) bank of the Mangoky river. It is close to the Bevoay village, in the Beroroha district, Atsimo-Andrefana region of southwestern Madagascar. The baobab can be found on the southern edge of the Ampanonga Forest. Its GPS coordinates are $21^{\circ} 57.974^{\prime} \mathrm{S}, 043^{\circ} 52.202^{\prime} \mathrm{E}$ and the altitude is $60 \mathrm{~m}$. Mean annual rainfall in the area is around $400 \mathrm{~mm}$.

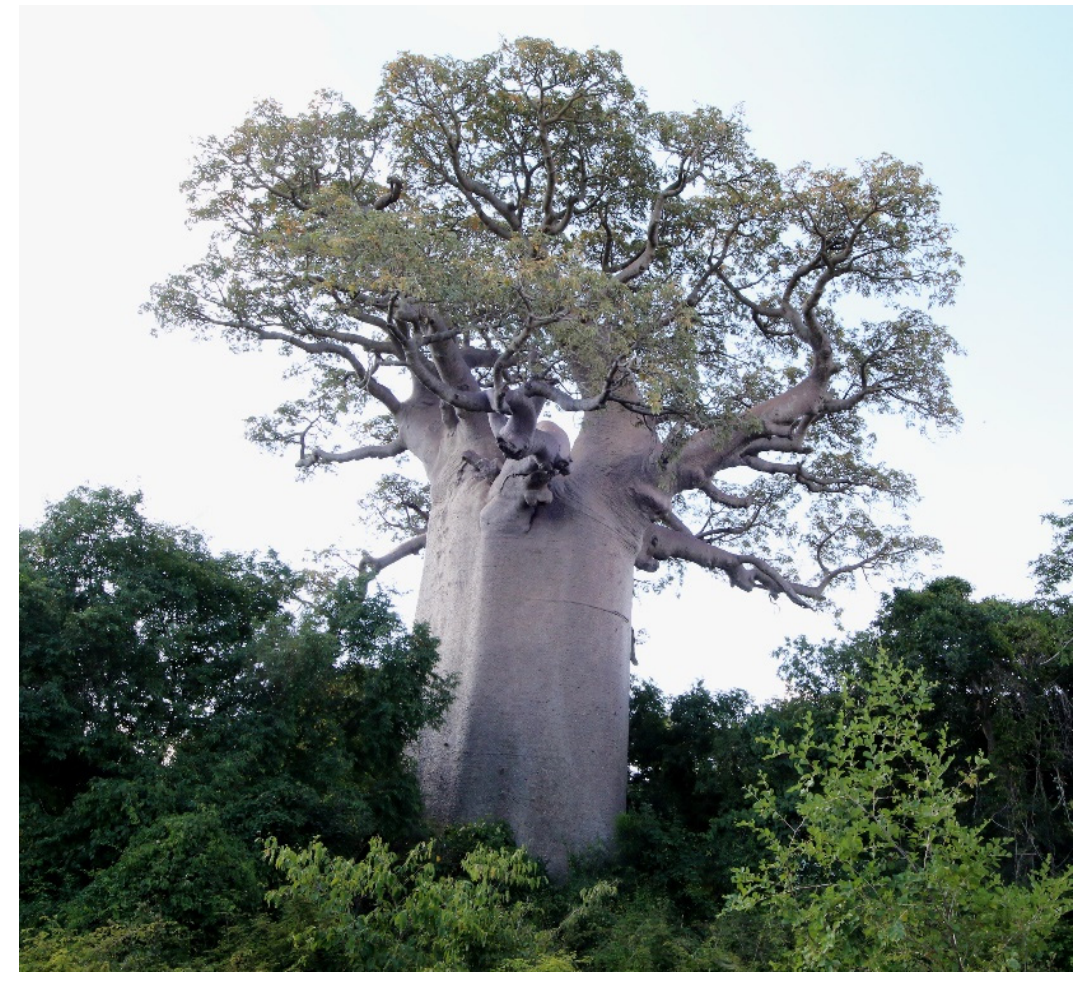

Figure 1. General view of the Giant of Bevoay taken from the south-east.

The baobab has a maximum height of $20.3 \mathrm{~m}$ and the restored circumference at breast height (cbh; at $1.30 \mathrm{~m}$ above ground level) is $21.03 \mathrm{~m}$ (Figure 1). Its base is situated in a $5 \mathrm{~m}$ deep depression.

The big columnar trunk has a tall horizontal fissure. It forks at the height of $14.8 \mathrm{~m}$ into several branches, out of which 3 are very large, with diametres up to $2 \mathrm{~m}$. According to the visual inspection and to the analysis of photographs, the quasi-cylindrical trunk is composed of 3 perfectly fused stems. The horizontal dimensions of the spectacular canopy are: 34.8 (WE) $x$ 29.2 (NS) m (Figure 2). 
The calculated wood volume of the baobab is $520 \mathrm{~m}^{3}$, out of which $480 \mathrm{~m}^{3}$ represents the trunk and $40 \mathrm{~m}^{3}$ the canopy. By this value, the Giant of Bevoay becomes the third largest Adansonia grandidieri in volume after the Big Reniala of Isosa and the famous fallen Tsitakakoike, both from the Andombiry Forest [21]. It is also bigger than any known African baobab.



Figure 2. The picture taken from south-west shows the very large canopy of the Giant of Bevoay.

Wood samples. Two wood samples, labelled B-1 and B-2, were extracted from the big trunk with an increment borer. The first sample B-1 was too short $(0.24 \mathrm{~m})$ for investigation. Therefore, we investigated only the second sample $\mathrm{B}-2$, collected at a height of $1.71 \mathrm{~m}$ above ground, which was sufficiently long $(0.78 \mathrm{~m})$. A number of five pieces/segments, each of the length of $10^{-3} \mathrm{~m}$ (marked from a to e), were extracted from determined positions of the sample.

AMS results and calibrated ages. Radiocarbon dates of the 5 sample segments are listed in Table 1. The radiocarbon dates are expressed in ${ }^{14} \mathrm{C}$ yr BP (radiocarbon years before present, i.e., before the reference year 1950). Radiocarbon dates and errors were rounded to the nearest year.

Calibrated (cal) ages, expressed in calendar years CE (CE, i.e., common era), are also shown in Table 1. The 1- $\sigma$ probability distribution (68.3\%) was selected to derive calibrated age ranges. For one sample segment (B-2e), 
the 1- $\sigma$ distribution is consistent with one range of calendar years. For two segments (B-2c, B-2d), the 1- $\sigma$ distribution is consistent with two ranges of calendar years, while for one sample segment (B-2b), with a low radiocarbon date, it corresponds to four ranges of calendar years. In these cases, the confidence interval of one range is considerably greater than that of the other(s); therefore, it was selected as the cal CE range of the segment for the purpose of this discussion.

Table 1. AMS Radiocarbon dating results and calibrated ages of samples collected from the Giant of Bevoay

\begin{tabular}{|c|c|c|c|c|c|}
\hline $\begin{array}{c}\text { Sample } \\
\text { code }\end{array}$ & $\begin{array}{l}\text { Depth }^{1} \\
\left.\text { [height }^{2}\right] \\
\text { (m) }\end{array}$ & $\begin{array}{c}\text { Radiocarbon } \\
\text { date [error] } \\
\left({ }^{14} \mathrm{C} \text { yr BP }\right)\end{array}$ & $\begin{array}{c}\text { Cal CE range } 1 \sigma \\
\text { [confidence } \\
\text { interval] }\end{array}$ & $\begin{array}{l}\text { Assigned } \\
\text { year } \\
\text { [error] } \\
\text { (cal CE) }\end{array}$ & $\begin{array}{c}\text { Sample } \\
\text { age } \\
\text { [error] } \\
\text { (cal CE) }\end{array}$ \\
\hline B-2a & $\begin{array}{c}0.02 \\
{[1.71]}\end{array}$ & - & - & $>1950$ & >Modern \\
\hline$B-2 b$ & $\begin{array}{c}0.15 \\
{[1.71]}\end{array}$ & $98[ \pm 34]$ & $\begin{array}{c}1710-1719(5.3 \%) \\
1813-1836(17.3 \%) \\
1855-1866(5.4 \%) \\
\mathbf{1 8 8 0 - 1 9 2 5}(\mathbf{4 0 . 4 \% )}\end{array}$ & $\begin{array}{c}1902 \\
{[ \pm 22]}\end{array}$ & $\begin{array}{c}120 \\
{[ \pm 20]}\end{array}$ \\
\hline B-2c & $\begin{array}{c}0.40 \\
{[1.71]}\end{array}$ & $269[ \pm 17]$ & $\begin{array}{l}1628-1680(31.2 \%) \\
1732-1803(37.0 \%)\end{array}$ & $\begin{array}{c}1767 \\
{[ \pm 35]}\end{array}$ & $\begin{array}{c}255 \\
{[ \pm 35]}\end{array}$ \\
\hline$B-2 d$ & $\begin{array}{c}0.65 \\
{[1.71]}\end{array}$ & $346[ \pm 45]$ & $\begin{array}{l}\mathbf{1 5 0 6 - 1 5 9 1}(\mathbf{5 4 . 5 \% )} \\
1618-1640(13.8 \%)\end{array}$ & $\begin{array}{l}1548 \\
{[ \pm 42]}\end{array}$ & $\begin{array}{c}470 \\
{[ \pm 40]}\end{array}$ \\
\hline B-2e & $\begin{array}{c}0.81 \\
{[1.71]}\end{array}$ & $525[ \pm 23]$ & $1424-1435(68.3 \%)$ & $\begin{array}{c}1434 \\
{[ \pm 10]}\end{array}$ & $\begin{array}{c}585 \\
{[ \pm 10]}\end{array}$ \\
\hline
\end{tabular}

${ }^{1}$ Depth in the wood from the sampling point.

2 Height above ground level.

For obtaining single calendar age values of sample segments, we derived a mean calendar age of each sample segment from the selected range (marked in bold). Sample/segment ages represent the difference between the year $2020 \mathrm{CE}$ and the mean value of the selected range, with the corresponding error. Sample ages and errors were rounded to the nearest $5 \mathrm{yr}$. We used this approach for selecting calibrated age ranges and single values for sample ages in all our previous articles on AMS radiocarbon dating of large and old angiosperm trees, especially of baobabs [7-17,19-22].

For one sample segment (B-2a), which was collected close to the bark, the sample age falls after $1950 \mathrm{CE}(0 \mathrm{BP})$, namely the ${ }^{14} \mathrm{C}$ activity, expressed by the ratio ${ }^{14} \mathrm{C} /{ }^{12} \mathrm{C}$, is greater than the standard activity in the reference year 1950. Such values, which correspond to negative radiocarbon dates, are termed greater than Modern (>Modern). In such cases, the dated wood is young, being formed after the year 1950 . 
ADRIAN PATRUT, ROXANA T. PATRUT, JEAN-MICHEL LEONG POCK-TSY, STEPHAN WOODBORNE, LASZLO RAKOSY, ILEANA-ANDREEA RATIU, JENŐ BODIS, PASCAL DANTHU

Dating results of samples (segments). The oldest dated segment, i.e., $\mathrm{B}-2 \mathrm{e}$, represents practically the sample end. It had a radiocarbon date of $525 \pm$ $23 \mathrm{BP}$, which corresponds to a calibrated age of $585 \pm 10$ calendar yr. The lower ages of the other three segments, i.e., B-2b, B-2c and B-2d, are in good accordance with their positions in the stems. Eventually, the negative radiocarbon date and the age of segment B-1a, shows that the stem from which was extracted the sample B-2 was not affected by the growth-stop phenomenon [13].

Architecture of the Giant of Bevoay. Our extended research on the African baobab revealed that very large specimens are always multi-stemmed $[10,13]$. This feature also applies to the large Malagasy baobabs, including the Grandidier baobabs [20,21]. As mentioned, the Giant of Bevoay consists of 3 perfectly fused stems. For this very large Grandidier baobab, the age sequence of segments extracted from the investigated sample, which was collected from the exterior, shows a continuous increase with the depth in the wood, see Table 1. This demonstrates that the baobab of Bevoay exhibits a cluster structure.

Age of the Giant of Bevoay. The age of the baobab can be estimated by extrapolating the age of the oldest dated sample segment, namely B-2e, to the presumptive pith of the corresponding stem. Sample segment B-2e, which has an age of $585 \pm 10 \mathrm{yr}$, originates from a depth of $0.81 \mathrm{~m}$ in the wood. In the sampling direction, the trunk has a diametre of $6.60 \mathrm{~m}$. Due to the cylindrical shape of the trunk, we can consider that the 3 fused stems, which build the trunk, have close dimensions and ages. In this case, the presumptive pith of the sampled stem is located at a distance of $1.65 \mathrm{~m}$ from the sampling point. In a conservative estimate, the age of the Giant of Bevoay is $825 \pm 50$ years.

\section{CONCLUSIONS}

Our research discloses the AMS radiocarbon dating results of the Giant of Bevoay, a very big Grandidier baobab, located on the lower course of the Mangoky river, Madagascar. The baobab is composed of 3 fused stems and presents a cluster structure. The wood volume of the Giant of Bevoay is $520 \mathrm{~m}^{3}$, which makes it the third largest known Grandidier baobab and also the third largest individual of all baobab species. Two wood samples were collected from the outer part of the trunk, out of which the longest was investigated. The oldest dated sample segment was found to have a radiocarbon date of $525 \pm$ $23 \mathrm{BP}$, which corresponds to a calibrated age of $585 \pm 10$ years. This value indicates that the Giant of Bevoay is $825 \pm 50$ years old. Therefore, one can state that the baobab of Bevoay started growing around the year $1200 \mathrm{CE}$. 


\section{EXPERIMENTAL SECTION}

Sample collection. The investigated wood sample was collected with a Haglöf $\mathrm{CH} 800$ increment borer (0.80 m long, $0.0108 \mathrm{~m}$ inner diametre). A number of four tiny pieces/segments, of the length of $10^{-3} \mathrm{~m}$, were extracted from predetermined positions along the sample. The segments were processed and investigated by AMS radiocarbon dating.

Sample preparation. The a-cellulose pretreatment method was used for removing soluble and mobile organic components [24]. The resulting samples were combusted to $\mathrm{CO}_{2}$, which was next reduced to graphite on iron catalyst $[25,26]$. The resulting graphite samples were analysed by AMS.

AMS measurements. The radiocarbon measurements were done at the AMS Facility of the iThemba LABS, Johannesburg, Gauteng, South Africa, using the $6 \mathrm{MV}$ Tandem AMS system [27]. In all cases, the obtained fraction modern values were finally converted to a radiocarbon date. The radiocarbon dates and errors were rounded to the nearest year.

Calibration. Radiocarbon dates were calibrated and converted into calendar ages with the OxCal v4.4 for Windows [28], by using the SHCal20 atmospheric data set [29].

\section{ACKNOWLEDGMENTS}

The investigation and sampling of the baobab was authorised by the Forestry Direction of the Ministry of Environment, Ecology and Forestry of Madagascar and by the Madagascar National Parks. The research was funded by the Romanian Ministry of National Education CNCS-UEFISCDI under grant PN-IIIP4-ID-PCE-2016-0776, No. 90/2017.

\section{REFERENCES}

1. G.E. Wickens, Kew Bull., 1982, 37(2), 172-209.

2. D.A. Baum, Ann. Mo. Bot. Gard., 1995, 82, 440-471.

3. G.E. Wickens, P. Lowe, "The Baobabs: Pachycauls of Africa, Madagascar and Australia", Springer, Dordrecht, 2008, pp. 232-234, 256-257, 295-296.

4. J.D. Pettigrew, L.K. Bell, A. Bhagwandin, E. Grinan, N. Jillani, J. Meyer, E. Wabuyele, C.E. Vickers, Taxon, 2013, 61, 1240-1250.

5. G.V. Cron, N. Karimi, K.L. Glennon, C.A. Udeh, E.T.F. Witkowski, S.M. Venter, A.E. Assobadjo, D.H. Mayne, D.A. Baum, Taxon, 2016, 65, 1037-1049.

6. A. Petignat, L. Jasper, "Baobabs of the world: The upside down trees of Madagascar, Africa and Australia", Struik Nature, Cape Town, 2015, pp. 16-86.

7. A. Patrut, K.F. von Reden, D.A. Lowy, A.H. Alberts, J.W. Pohlman, R. Wittmann, D. Gerlach, L. Xu, C.S. Mitchell, Tree Physiol., 2007, 27, 1569-1574. 
ADRIAN PATRUT, ROXANA T. PATRUT, JEAN-MICHEL LEONG POCK-TSY, STEPHAN WOODBORNE, LASZLO RAKOSY, ILEANA-ANDREEA RATIU, JENŐ BODIS, PASCAL DANTHU

8. A. Patrut, D.H. Mayne, K.F. von Reden, D.A. Lowy, R. Van Pelt, A.P. McNichol, M.L. Roberts, D. Margineanu, Radiocarbon, 2010, 52(2-3), 717-726.

9. A. Patrut, K.F. von Reden, R. Van Pelt, D.H. Mayne, D.A. Lowy, D. Margineanu, Ann. Forest Sci., 2011, 68, 93-103.

10. A. Patrut, S. Woodborne, R.T. Patrut, L. Rakosy, D.A. Lowy, G. Hall, K.F. von Reden, Nat. Plants, 2018, 4(7), 423-426.

11. A. Patrut, K.F. von Reden, D.H. Mayne, D.A. Lowy, R.T. Patrut, Nucl. Instrum. Methods Phys. Res. Sect. B, 2013, 294, 622-626.

12. A. Patrut, S. Woodborne, K.F. von Reden, G. Hall, M. Hofmeyr, D.A. Lowy, R.T. Patrut, PLOS One, 2015, 10(1): e0117193.

13. A. Patrut, S. Woodborne, K.F. von Reden, G. Hall, R.T. Patrut, L. Rakosy, J-M. Leong Pock Tsy, D.A. Lowy, D. Margineanu, Radiocarbon, 2017, 59(2), 435-448.

14. A. Patrut, L. Rakosy, R.T. Patrut, I.A. Ratiu, E. Forizs, D.A. Lowy, D. Margineanu, K.F. von Reden, Studia UBB Chemia, 2016, LXI, 4, 7-20.

15. A. Patrut, R.T. Patrut, L. Rakosy, D.A. Lowy, D. Margineanu, K.F. von Reden, Studia UBB Chemia, 2019, LXIV, 2 (II), 411-419.

16. A. Patrut, S. Woodborne, R.T. Patrut, G. Hall, L. Rakosy, C. Winterbach, K.F. von Reden, Forests, 2019, 10, 983-993.

17. A. Patrut, A. Garg, S. Woodborne, R.T. Patrut, L. Rakosy, I.A. Ratiu, PLOS One, 2020, 15(1): e0227352.

18. G. Vieilledent, C. Cornu, A. Cuni Sanchez, J-M. Leong Pock-Tsy, P. Danthu, Biological Conservation, 2013, 166, 11-22.

19. A. Patrut, K.F. von Reden, P. Danthu, J-M. Leong Pock Tsy, R.T. Patrut, D.A. Lowy, PLOS One, 2015, 10(3): e0121170.

20. A. Patrut, K.F. von Reden, P. Danthu, J-M. Leong Pock-Tsy, L. Rakosy, R.T. Patrut, D.A. Lowy, D. Margineanu, Nucl. Instrum. Methods Phys. Res. Sect. B, 2015, 361, 591-598.

21. R.T. Patrut, A. Patrut, J-M Leong Pock-Tsy, S. Woodborne, L. Rakosy, P. Danthu, I-A. Ratiu, J. Bodis, K.F. von Reden, Studia UBB Chemia, 2019, LXIV, 4, 131-139. doi:10.24193/subbchem.2019.4.10.

22. A. Patrut, R.T. Patrut, P. Danthu, J.-M. Leong Pock-Tsy, L. Rakosy, D.A. Lowy, K.F. von Reden, PLOS One, 2016, 11(1), e0146977.

23. H. Ravaomanalina, J. Razafimanahaka, "2016. Adansonia grandidieri." The IUCN Red List of Threatened Species 2016: e.T30388A64007143.

24. N.J. Loader, I. Robertson, A.C. Barker, V.R. Switsur, J.S. Waterhouse, Chem. Geol.,1997, 136(3), 313-317.

25. Z. Sofer, Anal. Chem., 1980, 52(8), 1389-1391.

26. J.S. Vogel, J.R. Southon, D.E. Nelson, T.A. Brown, Nucl. Instrum. Methods Phys. Res. Sect. B, 1984, 5, 289-293.

27. V.L. Mbele, S.M. Mullins, S.R. Winkler, S. Woodborne, Phys. Procedia, 2017, 90, 10-16.

28. C. Bronk Ramsey, Radiocarbon, 2009, 51, 337-360.

29. A.G. Hogg, T.J. Heaton, Q. Hua, J.G. Palmer, C.S.M. Turney, J. Southon, A. Bayliss, P.G. Blackwell, G. Boswijk, C.B. Ramsey, C. Pearson, F. Petchey, P.J. Reimer, R.W. Reimer, L. Wacher, Radiocarbon, 2020, 62(4), 759-778. 